\title{
Structural Pruning Effects on Stem and Trunk Strain in Wind
}

\author{
Edward F. Gilman, Jason W. Miesbauer, and F.J. Masters
}

\begin{abstract}
Pruning removes mass and reduces bending in the wind on the pruned stem. However, little is known about the impacts of structural pruning, which leaves some parts of the tree not pruned. This study was designed to measure change in stem and trunk strain $(\varepsilon)$ in turbulent wind from reducing the length of one side of a codominant stem pair. Trees were placed in front of a storm simulator with airfoils directing $22 \mathrm{~m} / \mathrm{s}$ wind at four frequencies $f(a)=0.3,0.5,0.7$, and $0.9 \mathrm{~Hz}$. Trees were subjected to 30 cycles at each $f(a)$ at each of four pruning doses-0\%, 33\%, 66\%, and $100 \%$ foliage (and associated branch mass) removed from the smaller codominant stem. This resulted in 16 trials on each of five trees. The non-pruned stem of a codominant pair experienced no $\varepsilon$ change in wind following reduction or removal of the competing codominant stem. Strain $(\varepsilon)$ on the pruned codominant stem and on the trunk below the union where stems join decreased linearly with pruning dose and increased with $f(a)$.

Key Words. Aspect Ratio; Biomechanics; Codominant Stems; Pruning; Reduction Cut; Removal Cut; Subordinate.
\end{abstract}

Branches that are small in relation to the trunk (i.e., those with a small aspect ratio) resist union (the point where stems join) failure because branch and trunk wood fibers intermingle as they overlap in the union (MacDaniels 1932). External loads similar to that from wind, ice, or snow focus bending stress at and beyond the union, causing branch failure instead of union failure on both small (Gilman 2003) and large (Kane et al. 2008) aspect ratio branches. Branch failure beyond the union serves as a mechanism to protect trunk and union against injuries that would expose them to organisms associated with decay. Instead of infecting the trunk, injured wood and the associated decay organisms are limited by the presence of a branch protection zone in unions with small aspect ratios (von Aufsess 1975; Eisner et al. 2002). Failure is more likely to occur at the union than along the branch when the aspect ratio is large (i.e., codominant stems and branches; Miller 1958; Edberg et al. 1994) because maximum bending stress occurs in union wood instead of branch wood. Without the intermingled wood fibers associated with stronger unions, excessive bending focuses stress along rays within the union resulting in its failure (Kane and Clouston 2008). Controlled experimentation (Smiley 2003) and observations by arborists (Costello and Berry 1991) demonstrate that attachment is weakened in unions with bark inclusions because the fibers do not intermingle.

Recognizing the importance of aspect ratio on union strength, structural or formative pruning was introduced to suppress growth rate of the largest stems competing with the leader in apple (Malus) orchards (Forshey et al. 1992). This manner of pruning reduces damage from storms, especially when they occur while trees are under load from heavy fruit set. Growth suppression was accomplished by removing the distal portion (using a reduction cut) and some lateral branches (using removal cuts) on the largest primary stems competing with the leader. This strategy encouraged growth in stems oriented more horizontally, which resist breakage in controlled environments (Miesbauer et al. 2014a) and in the field (Hauer et al. 1993; Duryea et al. 2007; Sellier and Fourcaud 2009). The suppressed growth rate on pruned stems coupled with enhanced growth in the non-pruned leader created a smaller aspect ratio (Gilman and Grabosky 2009; Kristoffersen 2010). Although recognized 
in scientific literature, and commonly practiced in apple orchards in North America and in shade tree nurseries in some regions (e.g., Anonymous 1998; Anonymous 2009; European Arboricultural Council 2005), subordination of codominant stems and branches is not commonly practiced in landscapes.

Removing stems and foliage in young trees by reducing or thinning the crown with pruning cuts reduces bending in wind; generally, an increase in mass removed from a stem reduces the load, center of pressure, bending moment (Smiley and Kane 2006), and motion (Gilman et al. 2008) of the pruned stem in a subsequent wind event. However, little is known about the impacts of structural pruning, which leaves some parts of the tree unpruned. Despite the decrease in aspect ratio (Gilman and Grabosky 2009) and resultant increase in union strength that occurs over time from structural pruning, reducing the length of some stems leaves others more exposed to wind. This study was designed to determine the impact of reducing the length of one side of a codominant stem pair on trunk and stem strain $(\varepsilon)$.

\section{MATERIALS AND METHODS}

\section{Trees}

Cutting-propagated Quercus virginiana Mill. Highrise $^{\oplus}$ trees were planted in 2002 from $10 \mathrm{~L}$ containers into field soil at a spacing of $3.8 \mathrm{~m}$. In December 2008 , five trees with two stems of nearly equal diameter (codominant stems) growing from a union approximately $5.2 \mathrm{~m}$ from the top of the tree were selected for study. Mean diameter of the smaller stem was $6.4 \mathrm{~cm}(\mathrm{SD}=0.5)$ and the larger stem was $7.9 \mathrm{~cm}(\mathrm{SD}=0.4)$. This resulted in a mean aspect ratio of 0.81 (range $=0.73$ to 0.90 ). There was no darkened wood normally associated with heartwood in the center of the stem cross section.

Trees (one at a time) with a mean trunk diameter of $12.4 \mathrm{~cm}(\mathrm{SD}=1.2$, range 11.1 to 14.2$)$ measured $30 \mathrm{~cm}$ from the ground and mean height of $7.8 \mathrm{~m}$ were severed at ground level and placed in a closed truck and driven approximately $10 \mathrm{~km}$ to a storm simulator (Gilman and Masters 2010). Once at the simulator, the trunk was shortened with a chain saw to standardize the distance (1.6 $\mathrm{m}$ ) between the cut and the union. This placed the codominant union approximately $30 \mathrm{~cm}$ above the bottom of the wind field (described below). A hole was drilled parallel to the ground near the bottom of trunk to allow insertion of a stabilizing carriage bolt. To secure the tree vertically, five 8 -cm-wide non-stretch straps were attached to a chain wrapped tightly around the trunk $0.9 \mathrm{~m}$ from the ground. Straps were distributed equally around the trunk and secured to bolts in a level concrete pad on the ground. This allowed approximately $1 \mathrm{~cm}$ horizontal trunk movement at this point on the trunk during each wind trial. Each tree was positioned so codominant stems were borne east and west with the smallest of the two stems on the west side; wind on trees was directed to the north (Figure 1).

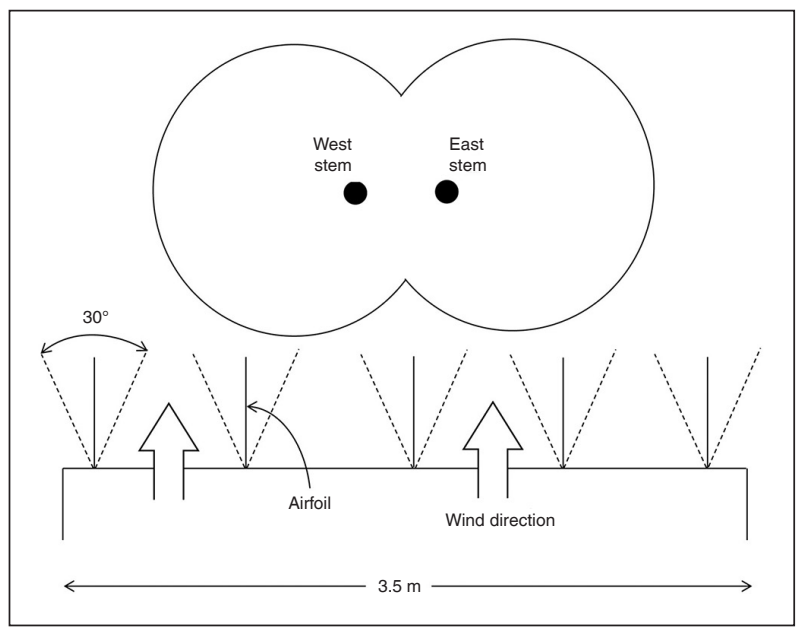

Figure 1. Storm simulator position indicating wind direction and codominant stem position. Airfoils rotated a total of $\mathbf{3 0}$ degrees east and west.

A smooth $25 \mathrm{~cm}$ long surface was prepared from 20 to $45 \mathrm{~cm}$ above the union on the west side of the west stem and the east side of the east stem with a hand plane. Similarly, a smooth surface was prepared from 20 to $45 \mathrm{~cm}$ below the union on the west side of the trunk. This allowed strain gauges to be mounted in these three positions without twisting from bark irregularities. A minimal amount of wood was removed in those few cases where shaving the bark was insufficient to prepare a smooth surface. Strain gauges (TML model PI-2-200, Tokyo Sokki Kenkyujo Co., Tokyo, Japan) were installed on each of these surfaces with two $14 \mathrm{~mm}$ long screws with a $3 \mathrm{~mm}$ diameter center shank reaching into the wood. The center of the strain gauge on the main trunk was $40 \mathrm{~cm}$ above the trunk-securing straps and $40 \mathrm{~cm}$ below the union. 
Diameter beyond any swelling associated with the union on all three stems was measured with a diameter tape at the center position of each strain gauge. Ratio of diameter, cross-sectional area, and fresh mass of the smaller (west) stem to that of the larger (i.e., aspect ratio) was calculated for each tree. Fresh mass was measured on parts removed from the pruned stem with each pruning dose. Length of each codominant stem from the union to the terminal bud was measured before pruning.

\section{Treatments and Test Procedure}

Starting from ambient conditions, wind generated from the storm simulator was gradually increased to $22 \mathrm{~m} / \mathrm{s}$ in 30 seconds. Airfoils turning 15 degrees east and west from due north created turbulence. Four airfoil frequencies $f(a)$ were then applied in random order to each of five trees: 0.3, 0.5, 0.7, and $0.9 \mathrm{~Hz}$ each for 30 complete cycles. This wind speed was chosen because preliminary testing with two extra trees from the same group showed that leaf loss was minimal and trunk strain $(\varepsilon)$ was unaffected by up to 20 minutes of blowing at any $f(a)$. Furthermore, the results of $\varepsilon$ response-in $22 \mathrm{~m} / \mathrm{s}$ wind at $0.9 \mathrm{~Hz}$ applied for 30 seconds tested hourlydid not vary from the time of cutting to five hours after cutting the trunk. Testing for each of the five test trees was completed within three hours of severing from the root system. Chosen $f(a)$ represent a range of natural frequencies $(f)$ reported for several species (Moore and Maguire 2004; Kane et al. 2014; Miesbauer et al. 2014b). This simulated a slow $(0.3 \mathrm{~Hz})$ to rapid $(0.9 \mathrm{~Hz})$ shift in position of the crown in the east to west and west to east directions as a result of wind redirection by airfoils. Ambient wind was $<2 \mathrm{~m} / \mathrm{s}$ in sunny conditions with a midday temperature range of $22^{\circ} \mathrm{C}$ to $28^{\circ} \mathrm{C}$ for the three days of testing. Strain gauge and anemometer measurement data were collected at $100 \mathrm{~Hz}$ using LabView software (National Instruments, Austin, Texas, U.S.), and recorded to a laptop computer.

Each tree was subjected to all four $f(a)$ prior to pruning (pruning dose $=0$ ). Pruning then removed from the smaller of the two stems (the western stem) a calculated $33 \%$ of pre-pruning foliage based on the cross-sectional area of the pruning cut relative to the base of the pruned stem on the same species (Grabosky and Gilman 2009) prior to the second set of four $f(a)$. Trees were pruned again to remove a calculated $66 \%$ of pre-pruning foliage from the smaller stem before blowing for a third set of $f(a)$. The final pruning dose removed $100 \%$ of the foliage by making a pruning cut at the codominant union prior to blowing for a fourth set of $f(a)$. The tree was subjected to a total of 16 wind events-four pruning doses $\times$ four $f(a)$. Each event was recorded on digital video from the vantage point of directly under the center of the contraction section exit at the airfoils.

\section{Data Analysis}

Strain on each of the three strain gauges individually was calculated as absolute value of the maximum $\varepsilon$ in the east plus west directions during each 30 -cycle wind event. General Linear Model and Stepwise Regression were used to construct Least Squares best fit equations predicting $\varepsilon$ from measured tree parameters at $P<0.05$. The Univariate procedure in SAS tested for normality. Slopes of lines were tested for equality using a t-test in ANOCOVA. Statistical analyses were performed in SAS version 9.2 (SAS Institute, Cary, North Carolina, U.S.).

\section{RESULTS AND DISCUSSION}

Strain on the pruned codominant stem increased with $f(a)$ and decreased with pruning dose (Figure 2a; Equation 1). While it might be tempting to suggest that the steeper slope with increasing $f(a)$ indicates pruning had a greater impact on reducing $\varepsilon$ in wind that changed direction quickest (i.e., $0.9 \mathrm{~Hz}$ ), the interaction was significant only at $P$ $<0.17$. The linear reduction in $\varepsilon$ with increasing pruning dose was similar to other studies with the same taxa where trunk movement diminished with percent foliage removed (Gilman and Grabosky 2009). This appears to coincide with other hardwoods (Smiley and Kane 2006) and conifers (Mayhead et al. 1975) where wind load or $\varepsilon$ decreased linearly with removal of foliage and shoot mass.

Despite the reduction in $\varepsilon$ with pruning dose on the pruned stem, there was no impact of pruning on the non-pruned stem (Figure 2b). This showed that each codominant stem reacted independent of the other. Pruning one of the two codominant stems did not expose the other (the non-pruned stem) to more $\varepsilon$ in $22 \mathrm{~m} / \mathrm{s}$ wind, despite a potential increased exposure to the wind field due to the missing terminal segment 
on the pruned stem. This implies that reducing a codominant stem to slow its growth rate and reduce aspect ratio-and thereby strengthening the union over time (Gilman 2003; Kristoffersen et al. 2010)-would not increase $\varepsilon$ on the nonpruned stem in a wind event simulated by this test. Wind blowing in a different direction or velocity than applied in the current study could result in different drag forces being placed on the tree. Although the smaller stem-the one that was pruned-could theoretically provide some protection for the non-pruned stem prior to pruning in a wind coming directly from the west (i.e., over the top of or through the crown of the pruned stem), this has yet to be demonstrated.

Strain on the non-pruned codominant stem increased with $f(a)$ (Figure 2b) and stem-diameter aspect ratio (Equation 2) at all pruning doses equally. There was no interaction between $f(a)$ and pruning dose $(P=0.91)$. Strain on the trunk below the union increased linearly with $f(a)$ and decreased with pruning dose (Figure 2c; Equation 4$)$, but there was no interaction $(P=0.17)$. Larger $\varepsilon$ from more bending at higher $f(a)$ (e.g., $0.9 \mathrm{~Hz}$ ) on all stems was due to greater east-west stem and trunk velocity (three times faster) compared to lower frequencies (e.g., $0.3 \mathrm{~Hz}$, Figure $2)$. More momentum $(\mathrm{p}=$ velocity $\times$ mass $)$ from greater velocity was almost certainly responsible for increased $\varepsilon$ and east-west distance traveled by the trunk at higher frequencies (Figure 2c; Equation 4). Increased distance traveled was not quantified but was apparent from visual obser-

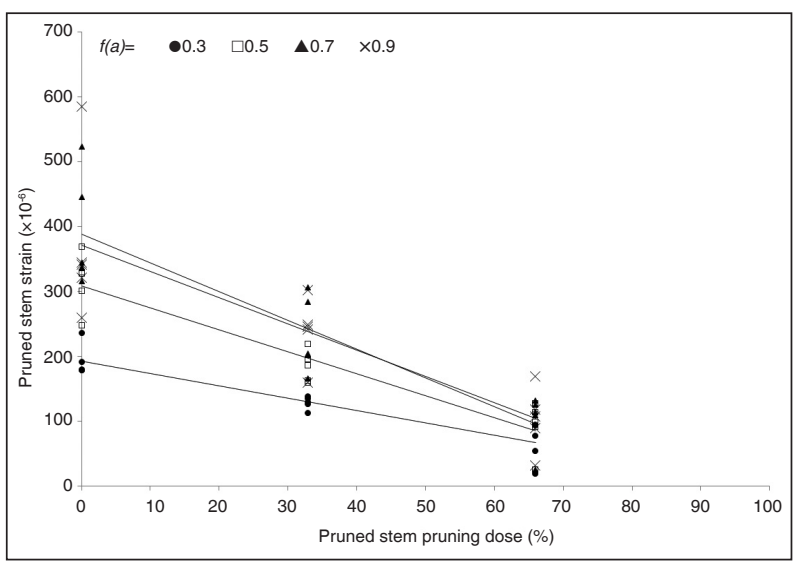

Figure 2a. Pruned stem strain $(\varepsilon)$ at increasing pruning dose and $0.3,0.5,0.7,0.9 \mathrm{~Hz} f(a)$. Equation $1: \varepsilon=2 \mathrm{e}^{-4}-3 \mathrm{e}^{-6}$ (pruning dose) $+2 \mathrm{e}^{-4} f(a) ; R^{2}=0.74 ; P<0.0001$; interaction $P=0.17$; $\mathrm{n}=\mathbf{3 0}$ airfoil cycles/data point.

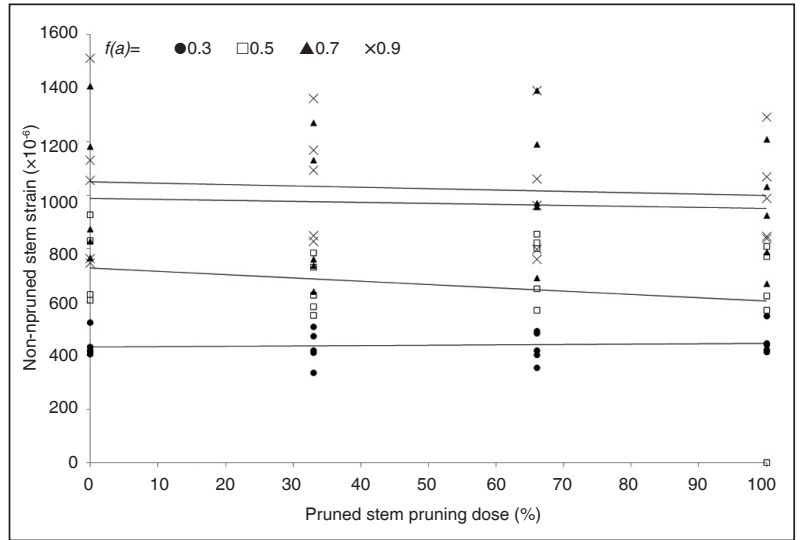

Figure $2 b$. Non-pruned stem strain $(\varepsilon)$ at increasing pruning dose and $0.3,0.5,0.7,0.9 \mathrm{~Hz} f(a)$. Equation 2: $\varepsilon=-6 \mathrm{e}^{-4}+$ $0.001 f(a)+0.001$ (stem-diameter aspect ratio); $R^{2}=0.67$; $P<0.0001$; interaction $P=0.91 ; \mathrm{n}=30$ airfoil cycles/data point.

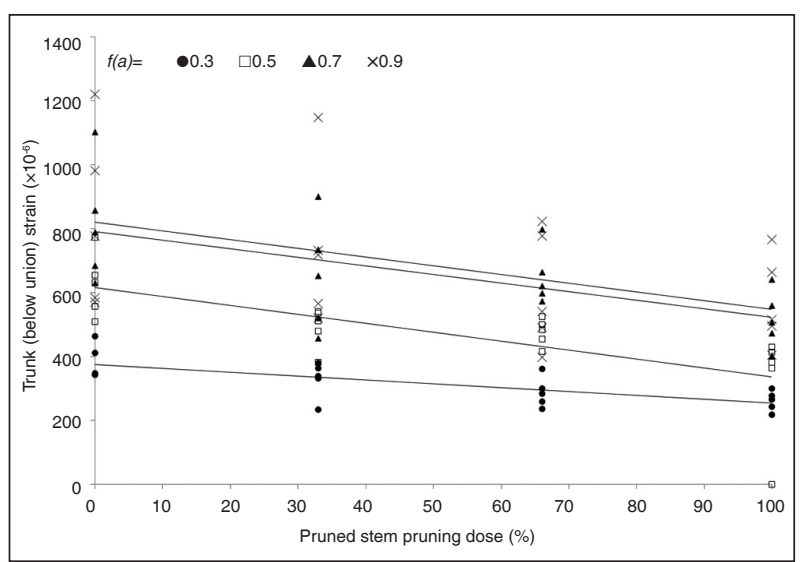

Figure 2c. Trunk strain $(\varepsilon)$ at increasing pruning dose and 0.3, 0.5, 0.7, $0.9 \mathrm{~Hz} f(a)$. Equation 4: $\varepsilon=2 \mathrm{e}^{-4}-2 \mathrm{e}^{-6}$ (pruning dose) $+7 e^{-4} f(a) ; R^{2}=0.56 ; P<0.0001$; interaction $P=0.17$; $\mathrm{n}=\mathbf{3 0}$ airfoil cycles/data point.

vation of the slow-motion videos of each trial. More momentum could also have resulted from the $f(a)$ reaching the natural $f$ of the trees, which ranged between 0.7 and $1.0 \mathrm{~Hz}$ for similarly sized Acer rubrum L. (Miesbauer et al. 2014b).

Removing 33\% of foliage (33\% pruning dose) corresponded to only a $20 \%$ reduction in stem/ foliage mass from the pruned stem but resulted in a $38 \%$ reduction in pruned stem $\varepsilon$. Removing $66 \%$ of foliage ( $51 \%$ of stem/foliage mass) resulted in a $71 \%$ reduction in $\varepsilon$. This showed that a reduction in mass from the end of the pruned stem yielded a disproportionately larger reduction in $\varepsilon$ at the base of the stem which likely reduced bending stress. The reduction in $\varepsilon$ was almost proportional to pruning dose. Coefficient 
for pruning dose in Equation $4\left(-2 \mathrm{e}^{-6}\right)$ was twothirds of that in Equation $1\left(-3 \mathrm{e}^{-6}\right)$, indicating that $\varepsilon$ was reduced on the pruned codominant stem more so than on the trunk. It is also possible that $\varepsilon$ was reduced more for the pruned stem than the trunk because the length of that individual stem was reduced, thereby reducing frontal area of that stem exposed to wind; whereas the total height of the tree was not reduced because the larger of the codominant stems was not pruned.

At the zero pruning dose and $0.9 \mathrm{~Hz} f(a)$, both codominant stems reached maximum $\varepsilon$ simultaneously (i.e., one did not lag in time behind the other) indicating they changed direction from west to east or from east to west at the same time (Figure 3, y-intercept was not different from zero, $P=0.68$ and 0.31 , respectively). However, at the $33 \%$ and $66 \%$ pruning dose treatments, the pruned stem changed direction sooner (lag time was greater) than the non-pruned stem (Figure 3; Equation 5; Equation 6) placing stems out of phase at the same $f(a)$. Maximum $\varepsilon$ occurred approximately 0.1 (33\% dose) and 0.2 (66\% dose) seconds sooner on pruned stems than non-pruned stems. Although more mass was removed with increasing pruning dose, codominant stem mass ratio was only significant in predicting $\varepsilon$ for the nonpruned stem (Equation 3). Because the pruned stem was shorter post-pruning, it moved less and experienced less $\varepsilon$ than the non-pruned stem. The momentum of the more flexible branches at the distal part of the more massive non-pruned stem likely contributed to the lag to maximum $\varepsilon$ (Dahle and Grabosky 2010). Despite the likely influence of stem length and flexibility on lag time, pruning dose percentage was more correlated with $\varepsilon$ than any measured length or mass attribute on the pruned stem and trunk below the union.

[3] $\varepsilon$ (non-pruned stem) $=-1 \mathrm{e}^{-5}+3 \mathrm{e}^{-4} f(a)+2 \mathrm{e}^{-4}$ (codominant stem mass ratio); $\mathrm{R}^{2}=0.50 ; P=0.0026$.

Increasing $\varepsilon$ on the non-pruned stem with increasing diameter of the other stem was attributed to increased similarity of stemdiameter aspect ratio (Equation 2) and codominant stem mass ratio (Equation 3) of the two stems as both approached 1.0. The crown moved, more or less, as one synchronized and tuned unit (in phase) on trees with larger ratios. In contrast, trees with smaller stemdiameter ratios or mass ratios appeared to be detuned because the less massive or smaller stem changed direction sooner than the larger (i.e., non-pruned) stem in response to change in airfoil direction (Equation 3). Miesbauer et al. (2014b) showed that trees pruned to impose small aspect ratios on primary branches had a higher trunk sway $f$ in simulated wind (pull-and-release test) than trees with large ratios, suggesting that trees with small ratios could also change direction quickly in wind.

Like the pruned codominant stem, trunk $\varepsilon$ below the union was reduced linearly with pruning dose for all $f(a)$ (equal slopes, $P=0.99$, Figure 2c). Trunk $\varepsilon$ was predictable by adding together $\varepsilon$ from both codominant stems (Equation 7; Figure 4) or from only the pruned stem (Equation 8; Figure 4). Strain $(\varepsilon)$ below the union was approximately one-half the sum of $\varepsilon$ of both codominant stems, as indicated by the coefficient of 0.55 (Figure 4). Strain $(\varepsilon)$ below the union was not expected to equal the sum of $\varepsilon$ on the two stems above because the trunk was larger and therefore stiffer than each stem, which made it more resistant to moving (i.e., less $\varepsilon$ ).

The trunk on pruned young trees sways with higher $f$ than before they were pruned due to less mass (Moore and Maguire 2004), less drag (Kane and Smiley 2006), and the distribution of mass within the crown (Miesbauer et al. 2014b). Less $\varepsilon$ from less foliage and mass on the pruned than the non-pruned stem (Figure 2) contributed to a detuning in the crown as the two stems moved slightly out of phase at the same $f(a)$. Detuning was likely caused by the mass of each, momentarily moving in opposite directions seen in windstorms (personal observations). Although the pruned stem changed direction sooner, it could not exhibit a higher sway frequency because that was dictated by the imposed $f(a)$. This was supported by increased lag time to maximum $\varepsilon$ between pruned and non-pruned stems with increasing pruning dose (Figure 3).

Although not previously shown empirically, detuning has been suggested as a desirable tree attribute that could play a role in resisting damage in certain types of wind storms (James 2003). Lower $\varepsilon$ (Figure $2 c$ ) at the higher pruning doses probably resulted from the reduction in motion from reduced 


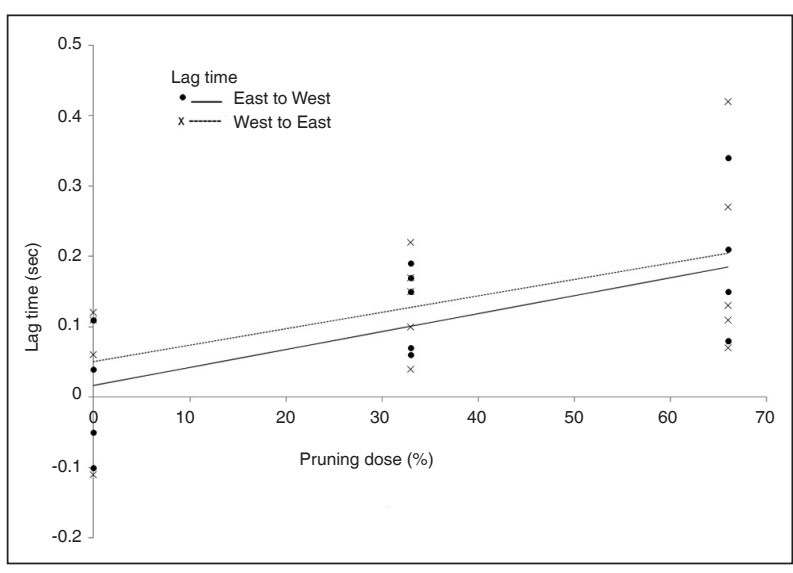

Figure 3. Number of seconds (lag time) non-pruned stem lagged behind pruned stem to reach maximum $\varepsilon$ as airfoil direction changed from west to east or east to west at $0.9 \mathrm{~Hz}$ $f(a)$. Equation 5: Lag time (west changing to east) $=0.0168$ +0.0026 (pruning dose); $R^{2}=0.41 ; P<0.0001 ; y$-intercept $=$ $0(P=0.68)$. Equation 6: Lag time (east changing to west) $=$ $0.0504+0.0023$ (pruning dose); $R^{2}=0.28 ; P<0.0001 ; y$-intercept $=0(P=0.31) ; n=30$ airfoil cycles/data point.

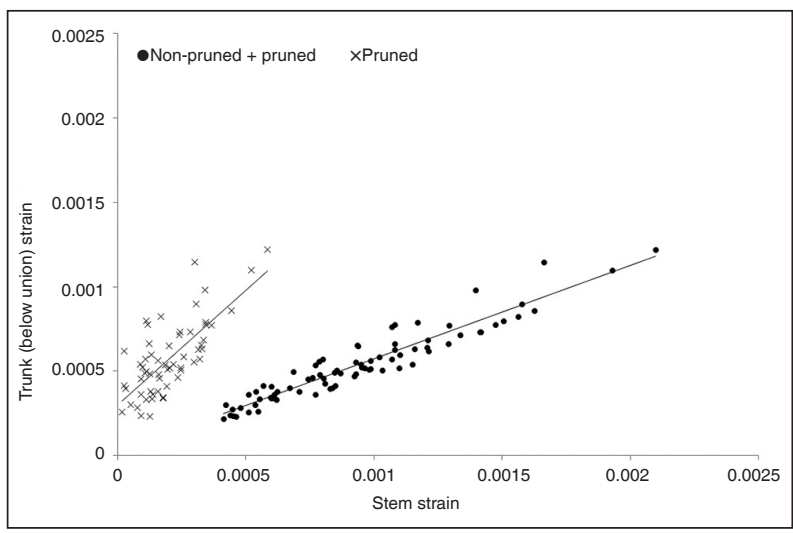

Figure 4. Relationship between trunk and stem strain $(\varepsilon)$. Equation 7: Trunk $\varepsilon$ (circles) $=2 \mathrm{e}^{-5}+0.55$ (non-pruned + pruned stem $\varepsilon) ; \mathbf{R}^{2}=0.90 ; \boldsymbol{P}<0.0001$. Equation 8: Trunk $\varepsilon$ $\left(x^{\prime} s\right)=3 e^{-4}+1.36$ (pruned stem $\left.\varepsilon\right) ; R^{2}=0.54 ; P<0.0001$. Each data point is mean of 30 airfoil cycles on one tree, at one frequency, and one pruning dose.

mass and length on the pruned stem (Smiley and Kane 2006; Gilman et al. 2008). This presumably reduced the momentum of the pruned stem and the trunk below the union, allowing them to change direction more quickly than before pruning.

Milne (1991) found that crown collision with neighboring trees contributed to half of overall damping of forest grown Picea sitchensis (Bong.) Carrière trees. Foliage and branch collision in the current study was observed (but not measured) in the terminal portion of the two stems as trees reached their maximum $\varepsilon$ in the westerly position and began transitioning east. The pruned (western) stem changed position and began moving east slightly before the non-pruned (east) stem, which was still traveling west (Figure 3), resulting in collisions between branches of the two stems. Collisions did not occur as trees changed direction from east to west because the pruned stem was on the west side of the tree making collision with the non-pruned stem improbable. Despite the lack of collisions transitioning east to west, lag time was identical to the west-east transition (Figure 3) suggesting that branch collision had no measurable impact on stem $\varepsilon$. This appears to be supported by Milne (1991), who found no damping from branch collisions in sustained ambient winds despite showing that collisions accounted for $50 \%$ of damping during manual sway tests with a rope.

Codominant stems are a recognized risk in certain trees due to their relatively weak attachment (Miller 1958; Smiley et al. 2011), but their removal results in large wounds that lack a branch protection zone (Eisner et al. 2002). This study showed that in lieu of removal, $\varepsilon$ on a stem can be suppressed by pruning the stem with a reduction cut without increasing $\varepsilon$ on remaining tree parts. In fact, trunk $\varepsilon$ below the union decreased with pruning. Union strength increases as growth on the reduced stem slows in response to the pruning treatment, causing a gradual reduction in aspect ratio (Kristoffersen et al. 2010). This combination of events can be used to structurally prune trees to enhance their resistance to storm damage while minimizing decay from large pruning cuts (von Aufsess 1975). Despite the reduction in trunk $\varepsilon$ below the union as a result of reducing one of the two stems, what remains unanswered is how $\varepsilon$ in union wood is affected by pruning one of the two codominant stems. The momentary motion of the two stems in opposite directions may influence how $\varepsilon$ is distributed within the union. Moreover, $\varepsilon$ on stems in this study was measured only in one axis (east to west); there were no measurements in any other direction. These issues should be investigated further. 


\section{CONCLUSIONS}

Reducing length by pruning one stem of a codominant stem pair reduced $\varepsilon$ on the pruned stem and the trunk below the union in $22 \mathrm{~m} / \mathrm{s}$ turbulent wind. Data suggest this could reduce damage in a storm when wind impacts both stems equally and passes through the union, as in this study. The non-pruned stem of the codominant pair experienced no $\varepsilon$ change in wind following reduction or removal of the competing codominant stem. Results could have been different if wind was applied so that one stem sheltered the other or if $\varepsilon$ was measured in different directions.

\section{LITERATURE CITED}

Anonymous. 1998. Grades and standards for nursery plants. Florida Department of Plant Industry, Gainesville, FL.

Anonymous. 2009. Guideline Specifications for Nursery Tree Quality. Urban Tree Foundation, Visalia, California, U.S.

Costello, L.R., and A.M. Berry. 1991. The California tree failure report program: An overview. Journal of Arboriculture 17:256-250.

Dahle, G.A., and J.C. Grabosky. 2010. Variation in modulus of elasticity (E) along Acer platanoides L. (Aceraceae) branches. Urban Forestry \& Urban Greening 9:227-233.

Duryea, M.L., E. Kampf, and R.C. Littell. 2007. Hurricanes and the urban forest: I. Effects on southeastern United States coastal plain tree species. Arboriculture \& Urban Forestry 33:83-97.

Edberg, J., A.M. Berry, and L.R. Costello. 1994. Patterns of tree failure in Monterey pine. Journal of Arboriculture 20:297-304.

Eisner, N., E.F. Gilman, and J. Grabosky. 2002. Branch morphology impacts compartmentalization of pruning wounds. Journal of Arboriculture 28:99-105.

European Arboricultural Council. 2005. European tree pruning guide, second edition. European Arboricultural Council. 20 pp.

Forshey, C.G., D.C. Elfving, and R.L. Stebbins. 1992. Training and pruning apple and pear trees. American Society for Horticulture Science. Alexandria, Virginia, U.S.

Gilman, E.F. 2003. Branch-to-stem diameter ratio affects strength of attachment. Journal of Arboriculture 29:291-294.

Gilman, E.F., and F. Masters. 2010. Effect of tree size, root pruning and production method on root growth and lateral stability of Quercus virginiana. Arboriculture \& Urban Forestry 36:281-291.

Gilman, E.F., and J. Grabosky. 2009. Growth partitioning three years following structural pruning of Quercus virginiana. Arboriculture \& Urban Forestry 35:281-286.

Gilman, E.F., J.C. Grabosky, S. Jones, and C. Harchick. 2008. Effects of pruning dose and type on trunk movement in tropical storm winds. Arboriculture \& Urban Forestry 34:13-19.

Hauer, R.J., W. Wang, and J.O. Dawson.1993. Ice storm damage to urban trees. Journal of Arboriculture 19:187-194.

James, K. 2003. Dynamic loading of trees. Journal of Arboriculture 29:165-171.

Kane, B., and E.T. Smiley. 2006. Drag coefficients and crown area estimation of red maple. Canadian Journal of Forest Research 36:1951-1958.
Kane, B., and P. Clouston. 2008. Tree pulling tests of large shade trees in the genus Acer. Arboriculture \& Urban Forestry 34:101-109.

Kane, B., R. Farrell, S.M. Zedaker, J.R. Loferski, and D.W. Smith. 2008. Failure mode and prediction of the strength of branch attachments. Arboriculture \& Urban Forestry 34:308-316.

Kane, B., Y. Modarres-Sadeghi, K. James, and M. Reiland. 2014. Effects of crown structure on the sway characteristics of large decurrent trees. Trees 28:151-159.

Kristoffersen, P., O. Bühler, S. Ugilt Larsen, and T.B. Randrup. 2010. Growth of newly established roadside trees in response to weed control and pruning. Arboriculture \& Urban Forestry 36:35-40.

MacDaniels, L.H. 1932. Factors affecting the breaking strength of apple tree crotches. Abstract, Proceedings American Society Horticulture Science 29:44

Mayhead, G.J., J.B.H. Gardiner, and D.W. Durrant. 1975. A report on the physical properties of conifers in relation to plantation stability. Forestry Commission Research and Development Division, Roslin, Midlothian, UK. 39 pp.

Miesbauer, J.W., E.F. Gilman, and M.C. Giurcanu. 2014b. Effects of tree crown structure on dynamic properties of Acer rubrum L. 'Florida Flame'. Arboriculture \& Urban Forestry 40(4):218-229.

Miesbauer, J.W., E.F. Gilman, F. Masters, and S. Nitesh. 2014a. Impact of branch orientation on breaking stress in Liriodendron tulipifera L. Urban Forestry \& Urban Greening 13:526-533.

Miller, V.J. 1958. Crotch influence on strength and breaking point of apple tree branches. Journal American Society Horticulture Science 73:27-32.

Milne, R. 1991. Dynamics of swaying of Picea sitchensis. Tree Physiology 9:383-399.

Moore, J.R., and D.A. Maguire. 2004. Natural sway frequencies and damping ratios of trees: Concepts, review, and synthesis of previous studies. Trees 18:195-203.

Sellier, D., and T. Fourcaud. 2009. Crown structure and wood properties: Influence on tree sway and response to high winds. American Journal of Botany 96:885-896.

Smiley, E.T. 2003. Does included bark reduce the strength of codominant stems? Journal of Arboriculture 29:104-106.

Smiley, E.T., and B. Kane. 2006. Effects of pruning type on wind loading of Acer rubrum. Arboriculture \& Urban Forestry 32:33-40.

Smiley, E.T., N. Matheny, and S. Lilly. 2011. Tree Risk Assessment. International Society of Arboriculture, Champaign, Illinois, U.S..

von Aufsess, H. 1975. The formation of a protective zone at the base of branches of broad-leaved and coniferous trees and its effectiveness in preventing fungi from penetrating into the heartwood of living trees. Forstwissen Centralblatt 94:140-152.

Edward F. Gilman (corresponding author)

Environmental Horticulture Department

University of Florida

Jason W. Miesbauer

Environmental Horticulture Department

University of Florida

F.J. Masters

Civil and Coastal Engineering Departments

University of Florida 
Zusammenfassung. Rückschnitt vermindert die Masse und reduziert an dem zurück geschnittenen Stamm die Biegung im Wind. Dennoch ist wenig bekannt über den Einfluss von strukturellem Rückschnitt, bei welchem einige Teile der Krone nicht geschnitten werden. Diese Studie wurde erstellt, um die Veränderung der Stamm- und Basis-Verformung $(\varepsilon)$ in turbulentem Wind zu messen, wenn nur ein Stamm von zwei kodominanten Stämmen in der Länge reduziert wird. Die Bäume wurden vor einen Sturmsimulator mit Tragflächen platziert, der Wind $(22 \mathrm{~m} / \mathrm{s})$ mit vier Frequenzen $f(a)=0.3,0.5,0.7$, und $0.9 \mathrm{~Hz}$. erzeugen kann. Die Bäume wurden 30 Zyklen ausgesetzt an jeder $f(a)$ an je einer von vier Rückschnittgraden, wobei $0 \%, 33 \%, 66 \%$ und $100 \%$ der Blattmasse (und des assoziierten Astwerks) vom kleineren der kodominanten Stämme entfernt wurde. Das resultierte in 16 Versuchen an jedem von fünf Bäumen. Der unbeschnittene Stamm eines kodominanten Paares erfuhr keine $(\varepsilon)$-Veränderung im Wind, nachdem der konkurrierende, kodominante Stamm zurückgeschnitten oder entfernt wurde. Die Verformung $(\varepsilon)$ an dem geschnittenen kodominanten Stamm und der Basis unterhalb der Vereinigung, sank linear mit dem Grad des Rückschnitts und stieg mit $f(a)$ an.

Resumen. La poda elimina masa y reduce la flexión por el viento en el tallo podado. Sin embargo, poco se sabe acerca de los impactos de la poda estructural, la cual deja algunas partes del árbol no podadas. Este estudio fue diseñado para medir los cambios en el tallo y el tronco $(\varepsilon)$ por vientos turbulentos mediante la reducción de la longitud de tallos codominantes. Los árboles fueron colocados frente de un simulador de tormentas a vientos de $22 \mathrm{~m} / \mathrm{s}$ en cuatro frecuencias $\mathrm{f}(\mathrm{a})=0,3,0,5,0,7$, y $0,9 \mathrm{~Hz}$. Los árboles fueron sometidos a 30 ciclos en cada $f(a)$ en cuatro dosis de poda $(0 \%, 33 \%$, $66 \%$, y $100 \%$ de follaje y de masa de ramas asociada) removida del tallo codominante más pequeño. Esto resultó en 16 ensayos en cada uno de cinco árboles. El tallo no podado de un par codominante no experimentó cambio $\varepsilon$ en el viento después de la reducción o eliminación del tallo codominante. La tensión $(\varepsilon)$ en el vástago codominante podado y en el tronco por debajo de la unión donde se unen los tallos disminuyó linealmente con la dosis y el aumento con $f(a)$. 